\title{
Community Leadership, Diaspora, and Ezra- Nehemiah: Continuing the Conversation with Gary Knoppers
}

\author{
LOUIS C. JONKER (STELLENBOSCH UNIVERSITY)
}

\begin{abstract}
This article examines the last contributions that Gary Knoppers made to the study of Ezra-Nehemiah. In his last book, which was published posthumously, he examined the 'conspicious' disappearance of Zerubbabel from Ezra-Nehemiah (and from other prophetic literatures) as well as the surprising down-playing of the places Mizpah and Ramat Rahel that were-according to the archaeological record - important places during the post-exilic period. In his assessment, he shows a more prominent ideological-critical line of scholarship that had not been so overt in his very well-known work on Chronicles. This article engages in further debate with Knoppers regarding these contributions to the study of Ezra-Nehemiah.
\end{abstract}

KEYWORDS: Ezra-Nehemiah, community leadership, diaspora, Gary Knoppers, ideological-critical approach

\section{A INTRODUCTION}

Gerald N. Knoppers, better-known as Gary Knoppers, made an indelible mark on Old Testament studies. He is not only well-known for his excellent commentary on 1 Chronicles in the Anchor Bible series (two volumes), but also for ground-breaking articles and essays on this biblical book. However, his specialisation went much further than that; he also contributed significantly to

\footnotetext{
* Submitted: 21/06/2021; peer-reviewed:30/10/2021; accepted: 16/11/2021. Louis C. Jonker, "Community Leadership, Diaspora, and Ezra-Nehemiah: Continuing the Conversation with Gary Knoppers," Old Testament Essays 34 no. 3 (2021): 888 - 901. DOI: https://doi.org/10.17159/2312-3621/2021/v34n3a13.
} 
research on the Deuteronomistic History, ${ }^{1}$ the Pentateuch ${ }^{2}$ and Samaritan studies. ${ }^{3}$ In the last few years of his life, he started to focus on Ezra-Nehemiah. ${ }^{4}$

After his death, an almost complete manuscript of his last book was discovered on his computer. This book, published posthumously in 2021 with the title Prophets, Priests, and Promises: Essays on the Deuteronomistic History, Chronicles, and Ezra-Nehemiah, was edited by Christl M. Maier and Hugh G.M. Williamson who only had to complete some technicalities in the manuscript. Seven of the 15 chapters had been published before, but his work in chapters 13 and 14 on Ezra-Nehemiah were new.

Gary Knoppers has passed away but we, as scholars in the fields of Chronicles and Ezra-Nehemiah studies, Deuteronomistic History and even Pentateuchal research, have his great collection of books, articles and chapters to engage with in coming years. My last scholarly conversation with him at Notre Dame University in November 2017 was about Ezra-Nehemiah and the Diaspora communities, while he was preparing for his paper at the SBL Annual Meeting in Boston later that month (which turned out to be the last lecture that he delivered at an SBL Annual Meeting). ${ }^{5}$ Therefore, I choose to follow up on those discussions in this article, dwelling also on his views about community leadership and the relationship between Yehud and the Eastern Diaspora during the (late) Achaemenid period.

This discussion of his last publication aims at advancing his work even further in the (South) African context (that forms the main audience of Old Testament Essays) as well as engaging critically with some later trends in his scholarship that can be observed specifically in his last postuum publication.

1 E.g., Gary N. Knoppers, "The Relationship of the Deuteronomistic History to Chronicles: Was the Chronicler a Deuteronomist?" in Congress Volume Helsinki 2010 (ed. Martti Nissinen; Leiden: Brill, 2012), 307-341.

2 E.g., Gary N. Knoppers and Paul B. Harvey, "The Pentateuch in Ancient Mediterranean Context: The Publication of Local Lawcodes," in The Pentateuch as Torah: New Models for Understanding Its Promulgation and Acceptance (ed. Gary N. Knoppers and Bernard M. Levinson; Winona Lake: Eisenbrauns, 2007), 105-141; Gary N. Knoppers and Bernard M. Levinson, eds., The Pentateuch as Torah: New Models for Understanding Its Promulgation and Acceptance (Winona Lake: Eisenbrauns, 2007); Gary N. Knoppers, "Parallel Torahs and Inner-Scriptural Interpretation: The Jewish and Samaritan Pentateuchs in Historical Perspective," in The Pentateuch: International Perspectives on Current Research (ed. Thomas B. Dozeman; Tübingen: Mohr Siebeck, 2011), 507-531.

3 E.g., Gary N. Knoppers, Jews and Samaritans: The Origins and History of Their Early Relations (Oxford: Oxford University Press, 2013).

4 E.g., Gary N. Knoppers, "The Construction of Judean Diasporic Identity in EzraNehemiah," JHS 15/3 (2015): 1-29.

5 The topic of his paper at the 2017 SBL Annual Meeting was "Argumentum ex silentio? Ramat Rachel and Ezra-Nehemiah." 
Although no attempt is made here to contextualise his views on community leadership in an African context, the article aims at introducing African readership to some peculiarities in Ezra-Nehemiah which can potentially enrich contemporary discourses on community leadership on the continent. It illustrates - through Knoppers' work - that biblical texts reflect the ideological and even political ideals of the ancient communities that brought about this literature. In exploring the historical dimension of Ezra-Nehemiah - as Knoppers did in his studies - contemporary readers of the Bible are equipped to bring these texts to their own contexts.

\section{B KNOPPERS ON COMMUNITY LEADERSHIP AND POLITICAL ADMINISTRATION DURING THE ACHAEMENID IMPERIAL RULE IN YEHUD}

In chapter 3 of Knoppers' book, previously published in a work on periodisation in Israelite historiography, ${ }^{6}$ he gives a clear overview of the differences in approach to the construction of the Israelite past in, respectively, the Deuteronomistic History, Chronicles and Ezra-Nehemiah. He shows how selectivity characterises particularly Ezra-Nehemiah. He writes as follows:

In Ezra-Nehemiah, selectivity in allocation of coverage proves to be a powerful device to define and categorize history. By focusing readers' attention on select vignettes from the past, the authors establish present priorities and a larger view of how a minority community can survive in a world dominated by others. On one level, the story is all about postexilic Yehud, the struggles of its people and their renewed ties to temple, torah, town, and land. On another level, the story is all about how some members of the eastern diaspora came to influence events in Yehud over against internal resistance and local opposition. The work's carefully segmented allocation of coverage conspires toward a well-defined view of community identity and validates the actions of one particular group within the Jerusalem elite. Over against detractors, the work shows how diasporic leaders rebuild, reform, and reclaim the community's heritage with the support of their Persian overlords. In this manner, the work defends and promotes a certain identity for Yehud, at least an identity as the authors would like to have it. $^{7}$

The themes of community leadership in Yehud and the Diaspora realities of the time form the focus of the last part of Knoppers' book, particularly in the newly written chapters 13 and 14. In chapter 13, he focuses on the strange

6 Gary N. Knoppers, "Periodization in Ancient Israelite Historiography," in Periodisierung und Epochenbewusstsein im Alten Testament und seinem Umfeld (ed. Josef Wiesehöfer and Thomas Krüger; Stuttgart: Franz Steiner, 2012), 121-145.

7 Gary N. Knoppers (†), Prophets, Priests, and Promises: Essays on the Deuteronomistic History, Chronicles, and Ezra-Nehemiah (Leiden: Brill, 2021), 69. 
disappearance of Zerubbabel from biblical literature, in general, and from EzraNehemiah, in particular, and in chapter 14, on the enigma of why Mizpah and Ramat Rahel are hardly mentioned in Ezra-Nehemiah. Although Knoppers' interest is mainly historiographic, he also offers valuable insight into the sociopolitical and socio-religious dynamics of the latter part of the Achaemenid period. The issues of community leadership in the face of imperial royal ideology but also of diaspora-homeland relations inform his views thoroughly.

\section{The Disappearance of Zerubbabel from Biblical Literature}

Knoppers starts chapter 13 with a comparative description of how Jeshua, the high priest, and Zerubbabel, the governor, feature in the prophetic books of Haggai and Zech 1-8 on the one hand and in Ezra-Nehemiah on the other. Knoppers rightly indicates that the so-called "diarchic" leadership of Jeshua and Zerubbabel has been the topic of many enthusiastic studies about a "theocratic" dispensation in Yehud's politics (and this matter will again be discussed below). Knoppers observes, however, that in Ezra-Nehemiah (as well as in the other prophetic sources) "Zerubbabel seems to vanish from the very source that charts his service and lauds his efforts." complicated by the peculiar fact that the completion of the temple and its public dedication are not mentioned in Haggai and Zechariah. It is at this point that Knoppers moves beyond his mere historiographic interest in the disappearance of Zerubbabel to some deliberations about the theo-political perspectives reflected in Ezra-Nehemiah. He writes:

In my judgment, the peculiar historiographic, political, and theological interests of the writers of Ezra-Nehemiah have not been sufficiently taken into account in assessing the fate of Zerubbabel. The extent to which the ideological interests of the writers of EzraNehemiah differ from those of Haggai and Zechariah deserves greater scrutiny. In particular, the theopolitical perspectives promoted by Ezra-Nehemiah toward the Davidic legacy, on the one hand, and the Achaemenid regime, on the other hand, need to be brought into a clearer focus [my emphasis $-\mathrm{LCJ}]$. $^{9}$

Knoppers takes up his own challenge by focusing on this aspect in his further reflections. After discussing a whole array of theories and different positions on whether Haggai, Zechariah, and Ezra-Nehemiah reflect a royalist ideology linked with the Davidide governor, Zerubbabel, and after providing his own close readings of the various texts, Knoppers suggests the following about the ideology from which the writers of Ezra-Nehemiah depart: "The writers of EzraNehemiah advocate a certain type of royalism, but that royalism is directed

8 Knoppers (†), Prophets, Priests, and Promises, 355-56.

9 Ibid., 358. 
toward the Persian monarchy, rather than toward reinvesting the Davidic line." 10 With this observation, Knoppers illustrates that royal aspirations and loyalty to the imperial centre went hand-in-hand for the writers of Ezra-Nehemiah. According to him, one of the reasons for the fairly positive stance towards Persia in Ezra-Nehemiah could have been that the writers were well aware that many of their relatives remained behind in Babylonia and were part of the Eastern Diaspora. Any kind of revolt or rebellion in the homeland would have had negative consequences for those Jews in the Diaspora as well. ${ }^{11}$

In his further description of the worldview of those authors behind EzraNehemiah, Knoppers argues that "Jerusalem, the people, Judah, and the sanctuary are critical components of corporate identity, but the Davidic promises ... are not." ${ }^{12}$ He also explains the absence of any titles for Zerubbabel (who is never called 'governor' in Ezra-Nehemiah) and Jeshua (who is never called 'high priest' or 'chief priest') with reference to the favourable ideology of the writers of Ezra-Nehemiah towards Persian kingship and rule. The writers know well that Zerubbabel was a Davidide and that Jeshua was a priest, they nevertheless associate these leaders with the laity. The rebuilding and restoration of Jerusalem, the temple and Yehud are sketched as a collective effort and not the achievement of individual community leaders:

The rebuilding of the Jerusalem sanctuary is a substantial development in establishing an axis mundi with respect to Judah, but there is, as we have seen, a major departure from the past in that there is no longer a Davidic potentate ruling in Jerusalem. Instead, Persian emperors (Cyrus, Darius) fulfil this traditional Davidic responsibility. Moreover, inasmuch as the people working on the project are repatriated expatriates ("children of the exile" [בני הגלה]), the temple becomes a joint enterprise, uniting the sponsoring communities in the eastern diaspora (Ezra 1:4,6) and the homeland community. The very portrayal of the temple reconstruction effort projects, therefore, the

10 Ibid., 373. As a side note: Here we see the "almost ecumenical spirit" of Knoppers' scholarship, as Hugh Williamson calls it in the "Introduction" to the book. In Williamson's words: "Knoppers seeks to overcome some of the too-hastily and even polemically formulated depictions of relationships between the various post-exilic communities..." Hugh G. M. Williamson, Ezra and Nehemiah (Sheffield: JSOT Press, 1987), 12.

11 Cf. the following publications that also deal with the role of the Eastern Diaspora in that period: Peter R. Bedford, "Diaspora: Homeland Relations in Ezra-Nehemiah," VT 52/2 (2002): 147-165; Melody D. Knowles, Centrality Practiced: Jerusalem in the Religious Practice of Yehud and the Diaspora in the Persian Period (Atlanta: SBL Press, 2006); David A. DeSilva, "Jews in the Diaspora," in The World of the New Testament: Cultural, Social, and Historical Contexts (ed. Joel B. Green and Lee Martin McDonald; Grand Rapids: Baker Academic, 2013), 272-290.

12 Knoppers (†), Prophets, Priests, and Promises, 375. 
positive benefits of repatriated Judeans contributing to the rebuilding of homeland life within a larger imperial context. ${ }^{13}$

The prominence of foreign benefactors for the rebuilding efforts such as Cyrus, who is called "king" from Ezra 1 throughout, is also emphasised. This enables Knoppers come to the following conclusion: "If Judean society in the Second Commonwealth is a theocratic monarchy, the monarchy is Persian in nature."14

In these analyses, the ideological-critical approach of Knoppers emerges clearly - maybe even more clearly than in any of his earlier work.

\section{The Obscurity of Mizpah and Ramat Rahel in Ezra-Nehemiah}

The ideological-critical approach continues in chapter 14, also a newly written piece. In this chapter, Knoppers' focus is on the conspicuous virtual absence of Mizpah and Ramat Rahel in Ezra-Nehemiah. Archaeological evidence shows that these two sites enjoyed extensive administrative and political prominence during the Neo-Babylonian and Achaemenid periods. In this contribution, we again - like in so many of his other publications - observe how masterfully Knoppers lets archaeological and literary evidence interact and engage with one another. Knoppers indicates that his aim in chapter 14 is the following: "I wish to argue that the sharp disjunction between the material remains and the literary remains pertaining to the Neo-Babylonian, Persian, and early Hellenistic periods in Judah sheds welcome light on the nature and function of Ezra-Nehemiah [my emphasis - LCJ]." ${ }^{15}$ Again, his interest in the ideological fibre of Ezra-Nehemiah emerges clearly.

Knoppers notes that these two place names are simply cited alongside many others in the wall-building account in Neh 3:1-32, without revealing anything about their special importance during the Persian period. ${ }^{16}$ The two centres of Mizpah and Ramat Rahel are not revered for their economic and political importance, "[o]n the contrary, insofar as these sites appear at all, they do so as Judean settlements whose leaders participate in a communal Judean effort to rebuild Jerusalem's walls." ${ }^{17}$ Knoppers also sharply observes that these two centres are nowhere mentioned in connection with the community leaders, Sheshbazzar, Zerubbabel, Jeshua or even Ezra. A further peculiarity is that Mizpah is often mentioned favourably in earlier texts (such as Kings and Jeremiah), and in the later text in 1 Maccabees 3:46 where Judas Maccabeus takes recourse to Mizpah on account of its proximity to Jerusalem, but also of its

13 Ibid., 387.

14 Ibid., 382.

15 Ibid., 392.

16 Knoppers acknowledges that this section in Neh 3 is often seen as a late interpolation into the narrative, although he does not discuss this further or draw any consequences from it.

17 Knoppers (†), Prophets, Priests, and Promises, 397. 
former religious significance. The "down-playing" of Mizpah in Ezra-Nehemiah becomes conspicuous when all these texts are considered.

Knoppers proceeds to discuss four possible reasons for this silence on the importance of Mizpah and Ramat Rahel. First, the writers and editors of the book worked in a much later time period and therefore were ignorant of the importance of these places. Knoppers acknowledges that Ezra-Nehemiah most probably developed over a long period of time but refutes this argument by presenting sufficient evidence in later literary sources which confirms that Mizpah and Ramat Rahel are indeed revered for their importance.

A second possibility is that the writers were so absorbed in promoting the importance of the contributions of returned exilic leaders (Sheshbazzar, Zerubbabel, Jeshua, Ezra and Nehemiah) to the rebuilding of the religious institutions in Jerusalem; that they were simply oblivious to the socio-political circumstances in Yehud. Knoppers indicates that "much of the energy in this book stems from Judeans rooted in the eastern diaspora ..." and that "[i]t could even be argued that the writing was composed for an audience in the eastern diaspora to defend, if not valorize, the actions of repatriated expatriates in the homeland." 18 It can thus be accepted that the focus would not have been on places in Yehud.

Thirdly, present-day scholars and writers might be over-emphasising the historical importance of the two sites Mizpah and Ramat Rahel. With this point, Knoppers shows his self-criticism of our scholarship and acknowledges that we as modern-day scholars might also have our hidden biases for exaggerating the importance of these sites. However, he points out that, even if that may be the case, one should acknowledge that tremendous advances have been made in the field of archaeology of this area in the last decades, and that the marked difference in material culture between Mizpah and Ramat Rahel on the one hand, and Jerusalem on the other, should be taken seriously. The archaeological evidence shows that the size, population and importance of Jerusalem have been greatly exaggerated for this period, surely, under the influence of the biblical witnesses. Thus, Knoppers concludes that "these considerations suggest that... adjusting our understanding of the internal power dynamics of Judah during the Neo-Babylonian, Persian, and Hellenistic periods is warranted."19

Lastly, the authors of Ezra-Nehemiah were aware, at least to some degree, of the historical, political and economic importance of these two centres but they were actively suppressing their importance in favour of the centre whose cause they wanted to buttress, namely Jerusalem. As Knoppers puts it: "In other words, do the authors self-consciously create a counter-narrative about the history of life

18 Ibid., 402.
19 Ibid., 404. 
in Persian period Yehud to the dominant political and economic realities obtaining during this particular time?"20

Knoppers masterfully combines the second and fourth theories to show that Ezra-Nehemiah's counter-narrative aimed at exchanging centre and periphery during the Achaemenid rule. In his own words:

Inasmuch as Mizpah and Ramat Rahel factor at all in this story, they play only subsidiary roles. In the Neo-Babylonian and Persian periods, Mizpah and Ramat Rahel were two imperial centres that controlled the political and economic administration of the province, but in Ezra-Nehemiah Jerusalem is the center that attracts support from the periphery, including on one occasion from Judean leaders in Mizpah and Ramat Rahel. In the imperially constructed reality, Mizpa and Ramat Rahel are imperial outposts within a small sub-province located in the satrapy of Transeuphratene, but in the alternative reality constructed in Ezra-Nehemiah Mizpah and Ramat Rahel are tributaries of Jerusalem. ${ }^{21}$

This brings me to the point of expounding what I have learnt from these newly written chapters in Knoppers' last book and what trends, or developments one can observe there. How can his work be brought into interaction with other discourses in the field of Old Testament studies?

\section{KNOPPERS AND OTHER DISCOURSES IN THE FIELD}

\section{$1 \quad$ Methodological Discourses}

Gary Knoppers was a meticulous reader of biblical texts - we have witnessed that not only in his careful readings of texts from the Deuteronomistic History in conjunction with Chronicles, but also in his treatment of Ezra-Nehemiah as illustrated in chapters 13 and 14 of his last book. We know from his commentary on 1 Chronicles, as well as from other studies, how meticulously he attended to text-critical and other textual matters, including classical Greek sources and Qumran literature. We have also seen in his earlier work and in these latest treatments of Ezra-Nehemiah how masterfully he could synthesise the findings of his literary studies with archaeological evidence.

One aspect that was more sublime and in the background in his earlier work is the ideological-critical perspective that emerges so clearly here in his treatment of the leadership and diaspora matters in Ezra-Nehemiah. His treatment of the disappearance of Zerubbabel and the downplaying of community leaders in Yehud as well as his reflections on why - in EzraNehemiah - Mizpah and Ramat Rahel are mere shadows of what we know archaeologically about these sites in the late Persian and early Hellenistic periods

20 Ibid., 404.

21 Knoppers (†), Prophets, Priests, and Promises, 407. 
show his more overt engagement on this level. The dynamics of Yehud's colonial existence within an imperial context, while also being connected to the Eastern Diaspora communities, become prominent in Knoppers' reasoning. I am surely not categorising Gary Knoppers as a postcolonial critic in the customary sense of the term ${ }^{22}$ - but his awareness of the hybridity of relations including internal and external power relations as well as mimicry as a sublime colonial strategy to undermine the interests of the imperial centre give a fresh dimension to his latest work on Ezra-Nehemiah. This is probably what Hugh Williamson is also referring to when he says in the introduction to the book: "The final section ... brings some of Knoppers' most recent thinking to bear on parts of the books of Ezra and Nehemiah, and shows just how much new potential research we have lost by his death." 23

However, some criticism should also be expressed with reference to methodological matters. Although Knoppers is fully aware of the diachronic studies on Ezra-Nehemiah ${ }^{24}$ and frequently and abundantly references the scholars who have made contributions in this regard, his work on Ezra-Nehemiah does not fully integrate those diachronic insights into his arguments. His treatments often focus "on these works as complete writings" 25 (as he puts it in chapter 3). There is certainly place for such a focus but it would have emphasised the multi-vocality of the different writings in Ezra-Nehemiah even more, if the "inner-debates" in the growth process of the book and the ideological intentions or aims of the editors were also brought to bear on the results of the investigations. This critical remark does not invalidate Knoppers' arguments and conclusions on the community leadership's royal expectations and the mainlanddiaspora relations. However, by integrating some of the diachronic insights into his arguments, he could have deepened our understanding of the multi-vocality of the postexilic communities.

22 Jeremy Punt, Postcolonial Biblical Interpretation: Reframing Paul (Leiden: Brill, 2015).

23 Knoppers $(\dagger)$, Prophets, Priests, and Promises, 3.

24 E.g., Hugh G. M. Williamson, "The Composition of Ezra i-vi,” JTS 34 (1983): 130; Williamson, Ezra and Nehemiah; Joseph Blenkinsopp, Ezra-Nehemiah (London: SCM Press, 1988); Jacob L. Wright, Rebuilding Identity: The Nehemiah-Memoir and Its Earliest Readers (Berlin: De Gruyter, 2004); Juha Pakkala, Ezra the Scribe: The Development of Ezra 7-10 and Nehemiah 8 (Berlin: De Gruyter, 2004); Juha Pakkala, "The Original Independence of the Ezra Story in Ezra 7-10 and Neh 8," BN 129 (2006): 17-24; Raik Heck1, "The Composition of Ezra-Nehemiah as a Testimony for the Competition between the Temples in Jerusalem and on Mt. Gerizim in the Early Years of the Seleucid Rule over Judah," in The Bible, Qumran, and the Samaritans (ed. Magnar Kartveit and Gary N. Knoppers; Berlin: De Gruyter, 2018), 115-132.

25 Knoppers (†), Prophets, Priests, and Promises, 57. 


\section{Levels of Socio-Historic Existence in late Persian Period Yehud}

In my book, Defining All-Israel in Chronicles, ${ }^{26}$ I distinguished four levels of socio-historical existence during the late Persian and early Hellenistic periods in Yehud. The overarching level is obviously the imperial context. Under this umbrella, three further levels of socio-historical existence unfolded namely, first, the inter-provincial power relations (particularly in relation to Samaria and Mount Gerizim); second, the inter-tribal power relations between the memories of Benjaminite and Judean influence; and lastly the inner-cultic power relations in Jerusalem where different priestly factions competed for influence. The expression of the power relations on the last-mentioned levels were always subjugated to the imperial level. Knoppers' recent studies, ${ }^{27}$ and of some other scholars ${ }^{28}$ should lead to the revision of this four-tiered description of Yehud under Achaemenid power. The Diaspora existence, which is probably not as prominent in Chronicles as in Ezra-Nehemiah, should certainly be included to appreciate the power dynamics reflected in the latter. How the Diaspora level relates to the imperial level and particularly the inter-provincial level, remains, however, unclear; but Knoppers' new chapters on Ezra-Nehemiah certainly prompt us to reflect more intensely on this aspect.

\section{Pentateuchal Research on "Theocratic Revisions"}

A third, and last, observation that I want to make about Knoppers' last book is that Pentateuch scholars should take note of his views expressed - particularly in chapters 13 and 14 - on the nature of the community leadership in Yehud. Although it is criticised by some, the view of Reinhard Achenbach that some theocratic redactions brought the book of Numbers, and thereby the whole Pentateuch, to a close in the late Persian period has gained reasonable

26 Louis C. Jonker, Defining All-Israel in Chronicles: Multi-Levelled Identity Negotiation in Late Persian Period Yehud (Tübingen: Mohr Siebeck, 2016).

27 Knoppers, Jews and Samaritans; Knoppers, "The Construction of Judean Diasporic Identity."

28 Bedford, "Diaspora: Homeland Relations"; Wright, Rebuilding Identity; Rainer Albertz, "Purity Strategies and Political Interests in the Policy of Nehemiah," in Confronting the Past: Archaeological and Historical Essays on Ancient Israel in Honor of William G. Dever (ed. S. Gitin et al.; Winona Lake: Eisenbrauns, 2006), 199-206; Katherine E. Southwood, "And They Could not Understand Jewish Speech': Language, Ethnicity, and Nehemiah's Intermarriage Crisis," JTS 62/1 (2011): 1-19. 
consensus. ${ }^{29}$ Although Joel Weinberg's understanding of the concept ${ }^{30}$ has been abandoned in scholarship, ${ }^{31}$ Achenbach finds it helpful to typify the very late redactions of the Pentateuch as "theocratic." Achenbach sees a series of three theocratic revisers ("theokratische Bearbeiter") adding the bulk of the priestly materials in Numbers to the combined Hexateuch and Pentateuch Redactions in the first half of the 4 th century B.C.E. This was done, according to him, to provide a foundational legend for, what he calls, a "hierokratisch geführte israelitischen Theokratie." "32 The theocratic revision was limited to the book of Numbers and proceeded in three stages. The political background to this move, according to Achenbach, was the Achaemenid regime's loss of Egypt and the decline of the Persian imperial power in many regions of Syro-Palestine including Yehud. In these circumstances, new political aspirations could have emerged in Yehud and Jerusalem, which can be witnessed in the "theocratic" revisions of Numbers.

Knoppers mentions the matter of theocratic leadership when he discusses the disappearance of Zerubbabel and the "downplaying" of the other repatriate leaders. He concludes clearly: "If Judean society in the Second Commonwealth is a theocratic monarchy, the monarchy is Persian in nature." 33 This warrants further research on the nature of such a "theocratic" rule. What if the theocratic aspirations as expressed in the last revisions of Numbers were "Persian in nature"?

In chapter 15 of his book, Knoppers offers some more detailed notes on the issue in a footnote, commenting that Ezra's priestly credentials are confirmed in the genealogy of Ezra 7:5 although he is never called a "chief priest" or "high priest" in the book. In 1 Esdras, he is indeed called "high priest," whereas Josephus opted for "chief priest":

[Ezra] is, however, repeatedly referred to as such (o $\dot{\alpha} \rho \chi 1 \varepsilon \rho \varepsilon v \dot{\varsigma})$ in 1 Esd 9:39, 40, 49. In the work of Josephus (Ant. 11.121), which is dependent on 1 Esdras, Ezra is referred to as a chief priest $(\pi \rho \tilde{\omega} \tau o \varsigma$

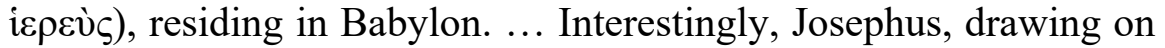
his main source (1 Esdras), speaks of Ezra functioning as a chief

29 Reinhard Achenbach, Die Vollendung der Tora: Studien zur Redaktionsgeschichte des Numeribuches im Kontext von Hexateuch und Pentateuch (Wiesbaden: Otto Harrassowitz, 2003); Reinhard Achenbach, "Der Pentateuch, seine Theokratischen Bearbeitungen und Josua-2 Könige," in Dernières Rédactions du Pentateuque, de l'Hexateuque et de l'Ennéateuque (ed. Konrad Schmid and Thomas C. Romer; Leuven: Universitaire Pers Leuven, 2007), 225-253.

30 Joel P. Weinberg, The Citizen-Temple Community (trans. Daniel L. SmithChristopher; Sheffield: JSOT Press, 1992).

31 Jeremiah W. Cataldo, "Persian Policy and the Yehud Community during Nehemiah," JSOT 28/2 (2003): 240-252; Jeremiah W. Cataldo, A Theocratic Yehud? Issues of Government in a Persian Province (New York: T\&T Clark, 2009).

32 Achenbach, Die Vollendung der Tora, 629-633.

33 Knoppers (†), Prophets, Priests, and Promises, 382. 


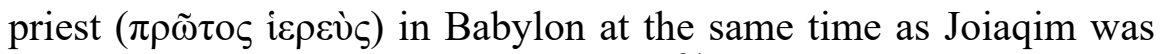

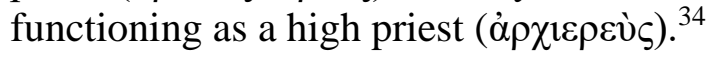

When Knoppers detects a tendency, as summarised above, that Ezra-Nehemiah reflects a deliberate attempt to ignore Zerubbabel's Davidide descent and Jeshua's priestly connection, more debates should be opened between EzraNehemiah (and Chronicles) scholarship, on the one hand, and Pentateuch studies, on the other. The theme of theocratic leadership should be revisited in light of Knoppers' findings.

\section{CONCLUSION}

I limit myself to these three perspectives on how Gary Knoppers' last book can stimulate our further debates in the field. Through our continuous engagement with the depth of this great scholar's work, we will remain in conversation with him for many years to come. He has stimulated so many scholarly discussions in our field and has rendered a great service to the community of Old Testament / Hebrew Bible scholarship. His influence will surely be seen in future generations of scholars working on the Old Testament, particularly, Chronicles and EzraNehemiah.

\section{E BIBLIOGRAPHY}

Achenbach, Reinhard. "Der Pentateuch, seine Theokratischen Bearbeitungen und Josua-2 Könige." Pages 225-253 in Dernières Rédactions du Pentateuque, de l'Hexateuque et de l'Ennéateuque. Edited by Konrad Schmid and Thomas C. Römer. Leuven: Universitaire Pers Leuven, 2007.

Die Vollendung der Tora: Studien zur Redaktionsgeschichte des Numeribuches im Kontext von Hexateuch und Pentateuch. BZABR 3. Wiesbaden: Otto Harrassowitz, 2003.

Albertz, Rainer. "Purity Strategies and Political Interests in the Policy of Nehemiah." Pages 199-206 in Confronting the Past: Archaeological and Historical Essays on Ancient Israel in Honor of William G. Dever. Edited by Seymour Gitin, J. Edward Wright and J. P. Dessel. Winona Lake: Eisenbrauns, 2006.

Bedford, Peter R. "Diaspora: Homeland Relations in Ezra-Nehemiah." Vetus Testamentum 52/2 (2002): 147-165.

Blenkinsopp, Joseph. Ezra-Nehemiah. London: SCM Press, 1988.

Cataldo, Jeremiah W. A Theocratic Yehud? Issues of Government in a Persian Province. New York, T\&T Clark, 2009.

"Persian Policy and the Yehud Community during Nehemiah." Journal for the Study of Old Testament 28/2 (2003): 240-252.

DeSilva, David A. "Jews in the Diaspora." Pages 272-290 in The World of the New Testament: Cultural, Social, and Historical Contexts. Edited by Joel B. Green and Lee Martin McDonald. Grand Rapids: Baker Academic, 2013.

Heckl, Raik. "The Composition of Ezra-Nehemiah as a Testimony for the Competition between the Temples in Jerusalem and on Mt. Gerizim in the Early Years of the

34 Ibid., 412. 
Seleucid Rule over Judah." Pages 115-132 in The Bible, Qumran, and the Samaritans. Edited by Magnar Kartveit and Gary N. Knoppers. Berlin: De Gruyter, 2018.

Jonker, Louis C. Defining All-Israel in Chronicles: Multi-Levelled Identity Negotiation in Late Persian Period Yehud. Forschungen zum Alten Testament 106. Tübingen: Mohr Siebeck, 2016.

Knoppers, Gary N. "Parallel Torahs and Inner-Scriptural Interpretation: The Jewish and Samaritan Pentateuchs in Historical Perspective." Pages 507-531 in The Pentateuch: International Perspectives on Current Research. Edited by Thomas B. Dozeman. Tübingen: Mohr Siebeck, 2011.

"Periodization in Ancient Israelite Historiography." Pages 121-145 in Periodisierung und Epochenbewusstsein im Alten Testament und seinem Umfeld. Edited by Josef Wiesehöfer and Thomas Krüger. Stuttgart: Franz Steiner, 2012. "The Relationship of the Deuteronomistic History to Chronicles: Was the Chronicler a Deuteronomist?" Pages 307-341 in Congress Volume Helsinki 2010. Edited by Martti Nissinen. Leiden: Brill, 2012.

Jews and Samaritans: The Origins and History of Their Early Relations. Oxford: Oxford University Press, 2013.

"The Construction of Judean Diasporic Identity in Ezra-Nehemiah." Journal of Hellenic Studies 15/3 (2015): 1-29.

Judah and Samaria in Postmonarchic Times: Essays on Their Histories and Literatures. FAT 129. Tübingen: Mohr Siebeck, 2019.

Knoppers ( $\dagger$ ), Gary N. Prophets, Priests, and Promises: Essays on the Deuteronomistic History, Chronicles, and Ezra-Nehemiah. Vetus Testamentum Supplements 186. Leiden: Brill, 2021.

Knoppers, Gary N. and Paul B. Harvey. "The Pentateuch in Ancient Mediterranean Context: The Publication of Local Lawcodes." Pages 105-141 in The Pentateuch as Torah: New Models for Understanding Its Promulgation and Acceptance. Edited by Gary N. Knoppers and Bernard M. Levinson. Winona Lake: Eisenbrauns, 2007.

Knoppers, Gary N. and Bernard M. Levinson, eds. The Pentateuch as Torah: New Models for Understanding Its Promulgation and Acceptance. Winona Lake: Eisenbrauns, 2007.

Knowles, Melody D. Centrality Practiced: Jerusalem in the Religious Practice of Yehud and the Diaspora in the Persian Period. Atlanta: SBL Press, 2006.

Pakkala, Juha. Ezra the Scribe: The Development of Ezra 7-10 and Nehemiah 8. Beihefte zur Zeitschrift für die Alttestamentliche Wissenschaft 347. Berlin: De Gruyter, 2004.

"The Original Independence of the Ezra Story in Ezra 7-10 and Neh 8." Biblische Notizen 129 (2006): 17-24.

Punt, Jeremy. Postcolonial Biblical Interpretation: Reframing Paul. Leiden: Brill, 2015.

Southwood, Katherine E. "“And They Could not Understand Jewish Speech': Language, Ethnicity, and Nehemiah's Intermarriage Crisis." Journal of Theological Studies 62/1 (2011): 1-19.

Weinberg, Joel P. The Citizen-Temple Community. Translated by Daniel L. SmithChristopher. Journal for the Study of the Old Testament Supplement Series 151. Sheffield: JSOT Press, 1992. 
Williamson, Hugh G. M. Ezra and Nehemiah. Sheffield: JSOT Press, 1987.

. "The Composition of Ezra i-vi." Journal of Theological Studies 34 (1983): 1-30.

Wright, Jacob L. Rebuilding Identity: The Nehemiah-Memoir and Its Earliest Readers. Beihefte zur Zeitschrift für die Alttestamentliche Wissenschaft 348. Berlin: Walter de Gruyter, 2004.

Louis C. Jonker, Stellenbosch University, lcj@sun.ac.za. ORCID: https://orcid.org/0000-0002-8181-0384. 